\title{
ON THE RELATIONSHIP BETWEEN FOOT PRESSURE DISTRIBUTION AND SOLE HARDNESS \\ DURING LONG-TIME STANDING
}

\author{
Xintao XIE \\ Physical Education College of Xi'an Technological University, Xi'an 710032, China, xxtyy2004@163.com \\ Received: 24.05 .2018 \\ Accepted: 15.10 .2018 \\ https://doi.org/10.24264/Ifj.18.4.1
}

\begin{abstract}
ON THE RELATIONSHIP BETWEEN FOOT PRESSURE DISTRIBUTION AND SOLE HARDNESS DURING LONG-TIME STANDING
ABSTRACT. For people like soldiers, doctors and traffic police who need to stand for a very long time at work, their feet are under long-time pressure; thus, their foot health affects their work and life. Based on the foot pressure sensing system Footscan. This paper studies the foot pressure distribution during long-time standing. According to the subjects' subjective assessment and experimental results, the author carries out statistical analysis on how different sole hardness can relieve the foot pressure during long-time standing. The conclusions are of great guiding significance to help people who need to stand for a long time at work scientifically relieve their foot pressure and select suitable footwear.

KEY WORDS: long-time standing, Footscan, sole hardness, subjective assessment, experiment
\end{abstract}

CONSIDERATII PRIVIND RELATIA DINTRE DISTRIBUTIA PRESIUNII PICIORULUI ŞI DURITATEA TĂLPII ÎN TIMPUL STATIONĂRII ÎNDELUNGATE REZUMAT. Pentru soldaţi, medici şi poliţişti rutieri, care trebuie să stea foarte mult în picioare la locul de muncă, picioarele acestora se află sub presiune îndelungată; astfel, sănătatea piciorului le afectează munca şi viaţa. Pe baza sistemului Footscan de detectare a presiunii piciorului, această lucrare studiază distribuţia presiunii piciorului în timpul staţionării îndelungate. Conform evaluării subiective a subiecţilor şi a rezultatelor experimentale, autorul efectuează analize statistice asupra modului în care diferite durităţi ale tălpii pot ameliora presiunea piciorului în timpul staţionării îndelungate. Concluziile sunt semnificative în a-i ajuta pe cei care sunt nevoiţi să stea mult timp în picioare la locul de muncă să-şi amelioreze presiunea piciorului pornind de la principii ştiinţifice şi să aleagă încălţămintea potrivită.

CUVINTE CHEIE: staţionare îndelungată, Footscan, duritatea tălpii, evaluare subiectivă, experiment

\section{CONSIDÉRATIONS SUR LA RELATION ENTRE LA DISTRIBUTION DE LA PRESSION DES PIEDS ET LA DURETÉ DE LA SEMELLE PENDANT LA STATION DEBOUT PROLONGÉE}

RÉSUMÉ. Pour les personnes comme les soldats, les médecins et les agents de la circulation qui doivent rester debout longtemps au travail, leurs pieds subissent une pression de longue durée; ainsi, la santé de leurs pieds affecte leur travail et leur vie. Basé sur le système Footscan de détection de pression du pied, cet article étudie la répartition de la pression du pied pendant la station debout prolongée. Selon l'évaluation subjective et les résultats expérimentaux des sujets, l'auteur effectue une analyse statistique de la mesure dans laquelle différentes duretés de la semelle peuvent soulager la pression du pied pendant la station debout prolongée. Les conclusions ont une grande importance pour aider les personnes qui ont besoin de rester debout longtemps au travail à réduire la pression exercée sur leurs pieds sur de bases scientifiques et à choisir des chaussures appropriées.

MOTS-CLÉS : station debout prolongée, Footscan, dureté de la semelle, évaluation subjective, expérience

* Correspondence to: Xintao XIE, Physical Education College of Xi'an Technological University, Xi'an 710032, China, xxtyy2004@163.com 


\section{INTRODUCTION}

Medically speaking, standing for longer than 40 minutes is identified as long-time standing. Occupations involving long-time standing include teachers, doctors, nurses, traffic police and guards [1]. During long-time standing, the feet are under pressure for a long time. The over-concentration of pressure on foot will cause foot muscle soreness and affect people's working status and physical and mental health. Researches on foot protection for these groups of people are still in the preliminary stage. Some shoe factories are already selling footprotection footwear, but due to lack of scientific design guidance, there are many deficiencies in footwear design, and those who need to stand for a long time at work also do not know how to choose footwear scientifically [2]. Besides, few researches have explored the relationship between foot comfort and different sole hardness during long-time standing from the theoretical perspective. As people are getting more concerned about their foot comfort and health, it becomes very necessary to scientifically analyse the relationship between foot pressure changes during long-time standing and sole hardness. Sole hardness is the key parameter of shoe comfort, and studies have shown that plantar pressure distribution is closely related to sole hardness [3]. In this paper, through both subjective assessment and objective test, we provide two ways of evaluation - quantitative and perceptual evaluation - for footwear comfort. Subjective assessment is mainly to measure shoe wearers' subjective feelings through questionnaire survey; objective evaluation is to test the foot pressure changes over the standing time with pressure measurement equipment [4]. With the help of the foot pressure test system - Footscan gait analysis system, the author conducted a foot pressure experiment with 15 young men within the same age group involved. Through reasonable experimental design and scientific scheme, the author collected statistics of foot pressure changes, foot fatigue start time and test shoe comfort of subjects on bare foot and wearing test shoes of different sole hardness and conducted comprehensive analysis on the experimental results based on the subjective assessment of the subjects. This study offers scientific guidance to improving the footwear of people who stand for a long time at work and provides shoe factories with relevant data basis and theoretical support. At the same time, it is of great significance to promoting plantar pressure and comfort research.

\section{OVERVIEW OF THE THEORETICAL CONCEPT OF FOOT PRESSURE}

\section{Static Mechanical Behaviors of Foot}

A human body stands with his/her two feet against the ground. The weight of the human body is transferred through muscles and bones to the feet. Through the spine and waist and then the legs, the body weight is divided into three pressure forces in each foot - one force is transferred to the heel, one to the forefoot and one to the buffer zone between the arch and the ground. Figure 1 shows the foot area map [5]. In the weight transfer process, foot pressure distribution is affected by various factors. Physiological factors include gender, weight, age, walking velocity and height, etc. Environmental factors include different footwear. For example, if a person wears high-heeled shoes, the pressure will increase on the medial side of the forefoot, while the pressure on the heel and the arch is relatively small [6]. Foot pressure measurement site, occupation of the subject and different sports are the external factors to the static pressure distribution of foot.

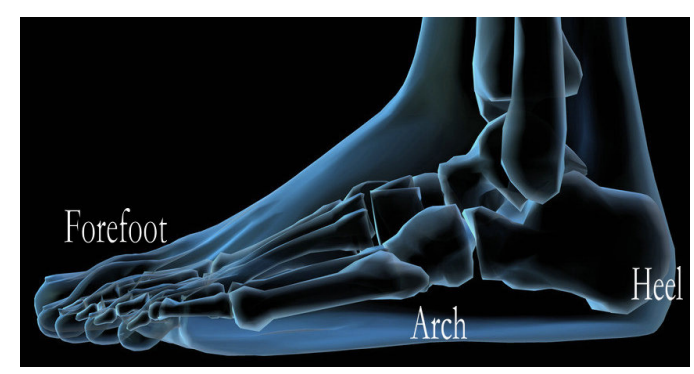

Figure 1. Foot area map

\section{Biomechanics of Foot Movement}

The research object of foot movement biomechanics is the pattern of foot movement when the human foot is under both internal muscle control and the action of an external force [7]. In the biomechanics of foot movement, in addition to the physiological conditions related to human body, footwear is also a key element. Footwear and human foot are an interactive 
whole. In different standing and movement postures, human body can adjust the posture to gain maximum comfort [8], and footwear design can help human body change the stress conditions of feet and ground [9].

The physiological characteristics of foot are basically fixed, but footwear can be designed and purchased according to demand, so adjusting foot pressure distribution mainly relies on footwear design. Foot pressure distribution and footwear design affect and improve each other. In this paper, the author recorded and analysed the plantar pressure distribution data of testees wearing shoes of different materials, hardness and heights and obtained the relationship between pressure distribution and shoe comfort, in an effort to help people design more suitable shoes for human.

\section{EXPERIMENTAL DESIGN FOR PLANTAR PRESSURE DISTRIBUTION DURING LONG- TIME STANDING}

\section{Experiment Apparatuses and Test Shoes}

Experiment apparatuses and testing instruments for foot pressure distribution mainly include Footscan gait analysis system, three pairs of test shoes with different hardness and hardness testing device.

The heights of the test shoes are around $2 \mathrm{~cm}$. To eliminate the impacts of shoe last, all test shoes are made by one manufacturer. The data of the test shoes measured by the hardness testing device and other apparatuses are listed in Table 1.

Table 1: Data of the test shoes

\begin{tabular}{ccccc}
\hline Shoes & Sole hardness & Heel-height $(\mathrm{cm})$ & Shoe size & Shoe type \\
\hline Test shoe 1 & 55 & 2.0 & 42 & casual shoes \\
Test shoe 2 & 64 & 1.9 & 42 & casual shoes \\
Test shoe 3 & 72 & 2.1 & 42 & leather shoes \\
\hline
\end{tabular}

\section{Test Subjects}

1. Age and gender. For persons of different age groups, the physiological characteristics of foot pressure and subjective assessment on the shoe comfort will also be different. In order to eliminate the impacts of age on the test results, this research selected 15 young men aged 23-25 as the test subjects [10].

2. Height and weight

Body height and weight also affect the comfort during long-time standing. In order to eliminate the impacts caused by these factors, the 15 young testees all had a height of 170 $172 \mathrm{~cm}$ and a weight of around 65Kg [11].

3. Illustration

All participants in the test are college students who were invited to the test through part-time invitation released in the campus network. All participants in the test are volunteers and will be compensated after the test.

\section{Experimental Design}

In this research, the author measured the plantar pressure distribution of individual subjects standing for a long time on bare foot and in different test shoes and recorded their subjective assessment [12].

Figure 2 shows the foot pressure distribution percentages of the test subjects during the static standing test measured by Footscan. 


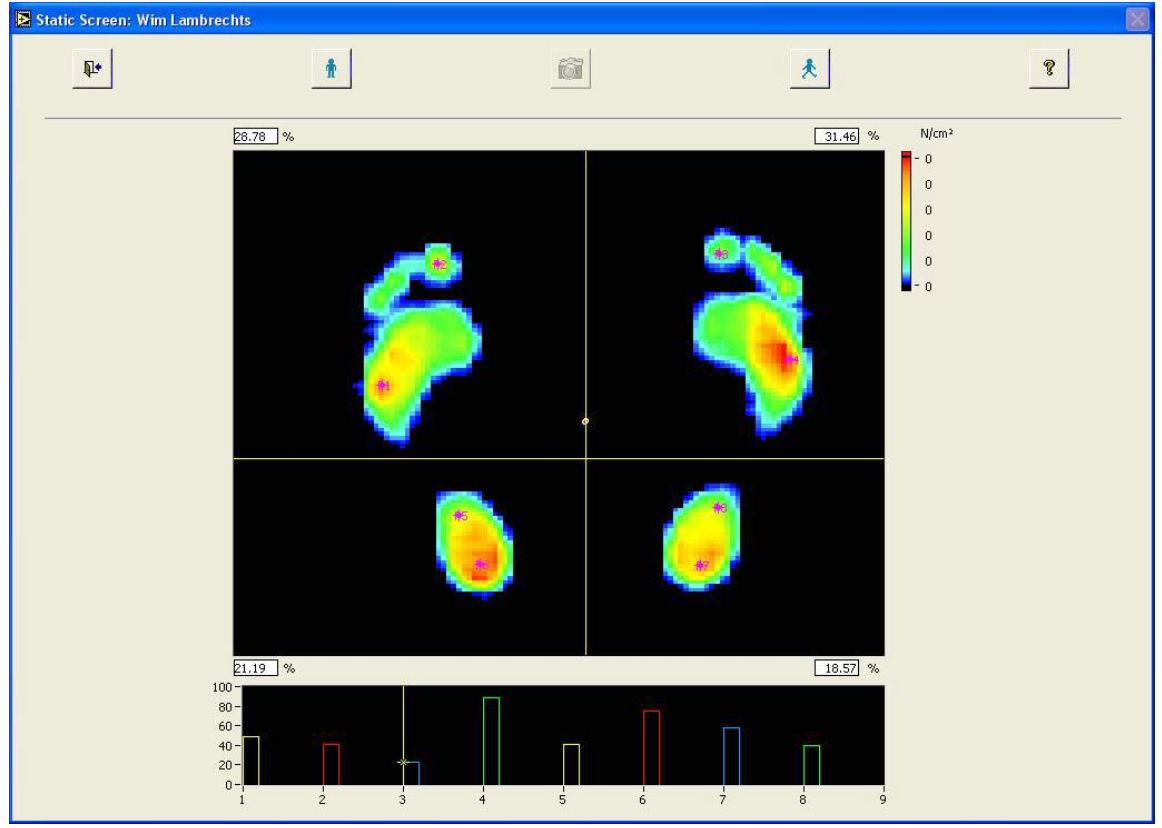

Figure 2. Static test pattern

The author designed the standing time to be $40 \mathrm{~min}$ and the pressure data sampling time to be $5 \mathrm{~min} /$ time [13]. Before the test, the testees had a rest for $30 \mathrm{~min}$ with their feet off the ground so that their foot conditions would be the same before the test started.

In order to reduce the impact of standing posture on the experimental results, the foot spacing should be between $40 \sim 60 \mathrm{~cm}$ provided that it satisfied the testees' usual standing habits.

Through a questionnaire survey on footwear comfort, the author recorded the testees' subjective assessment [14]. The author designed 4 levels in the pressure assessment: 1. Too much pressure, causing pain -4 points; 2. Too much pressure -3 points; 3 . A little too much pressure -2 points; 4 . Pressure comfort 1 point. For footwear assessment, there were 4 levels as well. Testees could rate the footwear as excellent, good, qualified and poor according to the comfort degree [15].

In this section, the author conducted preliminary analysis of the main experiment, collected information about the testees, carried out a preliminary experiment to determine the duration of the main experiment, provided preliminary training for testees and advised them of things to pay attention to. After that, the author completed the whole experiment, designed an objective assessment data system and subjective test table and completed the collection of experimental data and preliminary analysis.

\section{Experimental results and analysis of plantar pressure distribution during long-time standing}

According to the requirements of the experimental design, the author used Footscan to test the plantar pressure distribution, and at the same time conducted subjective assessment survey on footwear comfort. The experimental data and analysis results are as follows.

\section{Long-time Standing on Bare Foot}

First, the author collected statistics of plantar pressure distribution of 15 testees after they stood for $1 \mathrm{~min}$ to understand how different regions of a foot carried body weight. Table 2 shows the percentages of foot pressure of 15 testees. 
Table 2: Foot stress test results

\begin{tabular}{ccccccccc}
\hline & $\begin{array}{c}\text { Left forefoot } \\
(\%)\end{array}$ & $\begin{array}{c}\text { Left rear } \\
(\%)\end{array}$ & $\begin{array}{c}\text { Right forefoot } \\
(\%)\end{array}$ & $\begin{array}{c}\text { Right rear } \\
(\%)\end{array}$ & $\begin{array}{c}\text { Forefoot } \\
\text { total (\%) }\end{array}$ & $\begin{array}{c}\text { Rear total } \\
(\%)\end{array}$ & $\begin{array}{c}\text { Left foot } \\
\text { total (\%) }\end{array}$ & $\begin{array}{c}\text { Right foot } \\
\text { total (\%) }\end{array}$ \\
\hline A & 24.97 & 25.95 & 22.53 & 26.55 & 47.5 & 52.5 & 50.92 & 49.08 \\
B & 27.37 & 24.87 & 24.92 & 22.84 & 52.29 & 47.71 & 52.24 & 47.76 \\
C & 26.54 & 27.57 & 25.92 & 19.97 & 52.46 & 47.54 & 54.11 & 45.89 \\
D & 29.13 & 20.91 & 27.68 & 22.28 & 56.81 & 43.19 & 50.04 & 49.96 \\
E & 18.99 & 31.53 & 23.46 & 26.02 & 42.45 & 57.55 & 50.52 & 49.48 \\
F & 29.53 & 20.71 & 28.35 & 21.41 & 57.88 & 42.12 & 50.24 & 49.76 \\
G & 25.62 & 21.22 & 26.75 & 26.41 & 52.37 & 47.63 & 46.84 & 53.16 \\
H & 24.85 & 25.72 & 28.22 & 21.21 & 53.07 & 46.93 & 50.57 & 49.43 \\
I & 21.58 & 27.63 & 21.8 & 28.99 & 43.38 & 56.52 & 49.21 & 50.79 \\
J & 26.91 & 18.57 & 27.27 & 27.25 & 54.18 & 45.82 & 45.48 & 54.52 \\
K & 27.56 & 23.89 & 27.48 & 21.07 & 55.04 & 44.96 & 51.45 & 48.55 \\
L & 21.45 & 25.14 & 27.31 & 26.1 & 48.76 & 51.24 & 46.59 & 53.41 \\
M & 23.48 & 28.67 & 24.1 & 23.75 & 47.58 & 52.42 & 52.15 & 47.85 \\
N & 19.57 & 26.39 & 28.39 & 25.65 & 47.96 & 52.04 & 45.96 & 54.04 \\
O & 23.05 & 23.55 & 26.04 & 27.36 & 49.09 & 50.91 & 46.6 & 53.4 \\
\hline & & & & & & & & \\
\hline
\end{tabular}

From the data in the table, it can be seen that, out of the 15 testees, 8 had a forefoot pressure percentage of over $50 \%$; 7 had a rear foot pressure percentage of over $50 \%$; 9 had a total left foot pressure percentage of over $50 \%$ and 6 had a total right foot pressure percentage of over $50 \%$. This indicates that the pressure conditions of forefoot and rear foot during standing vary from person to person, and that there is no big difference between the pressure on the right and left feet. In the case of bare foot, the right forefoot bears the greatest pressure [16].

Then, the author collected the statistics of foot pressure distribution of one testee on bare foot at different time. Table 3 shows the pressure percentage of each part of the foot and the changes therein.

Table 3: Plantar pressure percentages of a testee on bare foot

\begin{tabular}{|c|c|c|c|c|c|c|c|c|}
\hline \multicolumn{5}{|c|}{ Percentage of stress (\%) } & \multicolumn{4}{|c|}{ Percentage of change (\%) } \\
\hline Time & $\begin{array}{c}\text { Left } \\
\text { forefoot }\end{array}$ & Left rear & $\begin{array}{l}\text { Right } \\
\text { forefoot }\end{array}$ & Right rear & $\begin{array}{c}\text { Left } \\
\text { forefoot }\end{array}$ & Left rear & $\begin{array}{l}\text { Right } \\
\text { forefoot }\end{array}$ & Right rear \\
\hline 2 & 25.78 & 24.9 & 23.13 & 26.19 & 0.81 & 1.05 & 0.6 & 0.36 \\
\hline 7 & 25.12 & 25.12 & 23.75 & 26.01 & 0.62 & 0.6 & 0.62 & 0.6 \\
\hline 12 & 24.85 & 25.24 & 22.98 & 26.93 & 0.5 & 0.26 & 0.47 & 0.71 \\
\hline 17 & 25.74 & 22.76 & 24.61 & 26.89 & 1.01 & 1.14 & 0.15 & 0.28 \\
\hline 22 & 24.14 & 26.07 & 23.04 & 26.75 & 0.72 & 0.53 & 0.09 & 0.1 \\
\hline 27 & 25.12 & 24.73 & 25.38 & 24.77 & 0.78 & 0.72 & 0.36 & 0.42 \\
\hline 32 & 25.48 & 25.93 & 24.48 & 24.11 & 0.47 & 0.28 & 0.5 & 0.69 \\
\hline 37 & 26.76 & 22.06 & 26.86 & 24.32 & 0.98 & 1.61 & 0.8 & 0.17 \\
\hline
\end{tabular}

The table shows data that were collected every $5 \mathrm{~min}$. From the data, it can be seen that, after $12 \mathrm{~min}$, the testee started to feel fatigue in his feet. Through self-adjustment, the foot pressure was relieved. Over time, the fatigue came more frequently. Other 15 testees felt fatigue for the first time within $8^{\sim} 13 \mathrm{~min}$. The comfortable time that could be maintained after self-adjustment became shorter and shorter.
Test on Shoes with Different Sole Hardness

One Testee Wearing Different Test Shoes

According to the experimental design, 15 young testees participated in the foot pressure distribution test by wearing shoes with different hardness.

Figure 3 shows the plantar pressure distribution of the testee $D$ in test shoes 1 in the first minute. 


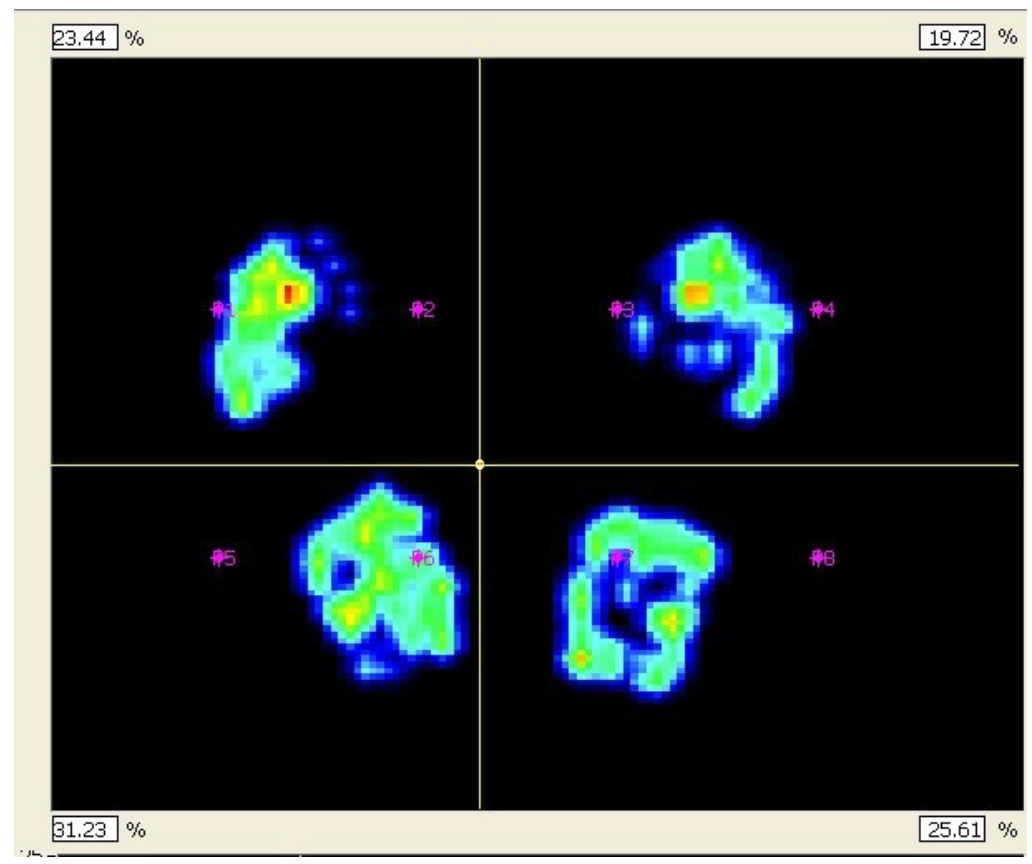

Figure 3. State of Testee D with shoes 1 in the first 1 minute

As shown in Figure 3, the foot pressure was mainly concentrated in the forefoot and the heel. The local pressure was too large while the regional coverage was small (the orange parts).

Figure 4 shows the plantar pressure distribution of the testee $D$ in test shoes 2 .

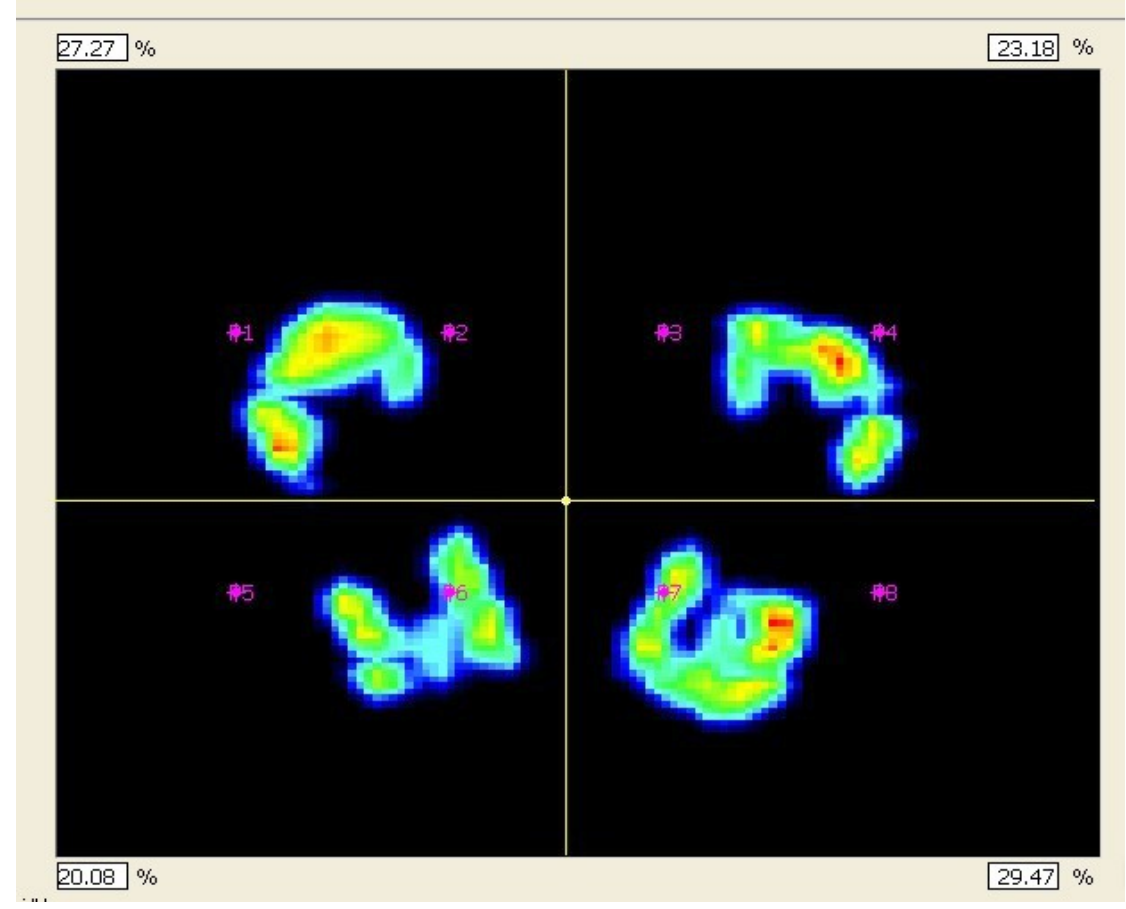

Figure 4 . Testers $D$ with shoes 2 for the first 1 minute state experiments

As shown in Figure 4, compared with shoes 1 , in the shoes 2 case, the pressure was too large and the area coverage was expanded the orange parts were expanded, indicating the feet carried more pressure.

Figure 5 shows the plantar pressure distribution of the testee $D$ in test shoes 3 . 


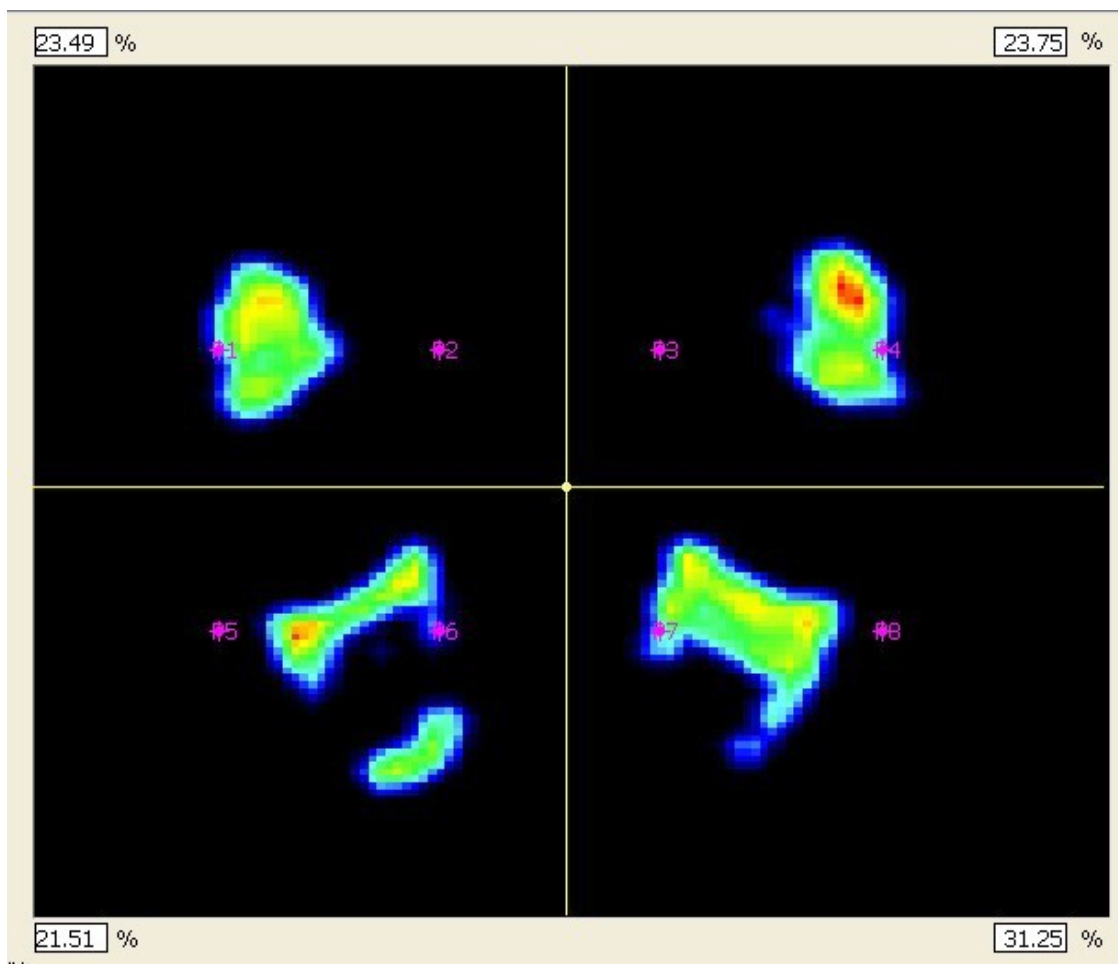

Figure 5. Testers $D$ with shoes 3 for the first 1 minute state experiments

Figure 5 shows the foot pressure distribution when the testee wore the test shoes 3. The hardness of the test shoes is: test shoes $3>$ test shoes $2>$ test shoes 1 . By comparing and analyzing the experimental results of the three pairs of test shoes, it can be seen that the higher the sole hardness is, the less the shoes can do to adjust foot pressure.

\section{Different Testees Wearing Different Test Shoes}

The test was to find out the first foot fatigue time for different testees wearing different test shoes. Table 4 shows the foot fatigue time for 15 young testees.

Table 4: Testee's foot fatigue time point

\begin{tabular}{|c|c|c|c|c|c|c|c|c|c|c|c|c|c|c|c|}
\hline Tester & $A$ & $B$ & $C$ & $\mathrm{D}$ & $E$ & $\mathrm{~F}$ & $\mathrm{G}$ & $\mathrm{H}$ & 1 & $\mathrm{~J}$ & $\mathrm{~K}$ & $\mathrm{~L}$ & $M$ & $\mathrm{~N}$ & 0 \\
\hline & & & & & & & Shoe 1 & & & & & & & & \\
\hline Time & 15 & 12 & 13 & 13 & 10 & 14 & $\begin{array}{l}16 \\
\text { Shoe } 2\end{array}$ & 13 & 5 & 16 & 7 & 14 & 8 & 15 & 11 \\
\hline Time & 25 & 22 & 23 & 20 & 20 & 12 & $\begin{array}{l}23 \\
\text { Shoe } 3\end{array}$ & 19 & 12 & 17 & 14 & 17 & 11 & 18 & 19 \\
\hline Time & 21 & 19 & 19 & 16 & 15 & 17 & 19 & 13 & 11 & 14 & 10 & 13 & 8 & 19 & 22 \\
\hline
\end{tabular}

From the data in the table, it can be seen that the average time after which the testees felt fatigue in their feet when wearing test shoes 1 was $12.1 \mathrm{~min}$; that the fatigue start time for test shoes 2 was $12 \sim 25 \mathrm{~min}$, with an average of $18 \mathrm{~min}$; and that the fatigue start time for test shoes 3 was $15.3 \mathrm{~min}$ on average.

\section{Subjective Assessment by Subjects}

\section{Subjective Assessment for Barefoot Test}

In the survey, testees on bare foot believed that it was the least comfortable to stand on bare foot. During the 40-min barefoot test, the feet were under too much pressure for over $20 \mathrm{~min}$ and that caused pain. The average rating given by the 15 testees on pressure was nearly 3 , 
indicating that the subjective perception of the testees standing on bare foot for a long time was too much pressure.

This is consistent with the experimental results - when standing on bare foot, the human body was poor at making self-adjustments and the pressure on feet was more concentrated.

\section{Subjective Assessment Given by Testees}

Wearing Different Test Shoes

People's subjective assessment on footwear comfort was always lagging. After the end of the shoe test, the author collected the opinions of the 15 testees on the shoes with three different hardness. 14 interviewees rated test shoes 2 as good, shoes 1 as qualified and shoes 3 as poor.

Judging from the objective test data and subjective assessment, the test shoes 2 (casual shoes with a sole hardness of 64 ) are the best.

\section{Discussion of Research Results}

The main innovations of this paper are to explore foot comfort and different sole hardness during long-time standing. From the perspective of the change of plantar pressure, combined with the hardness of the sole and the standing time, the comfort of the shoes is studied. The comprehensive evaluation method was adopted which combines subjective and objective evaluation method to study the comfort of longterm standing shoes. The experimental results obtained from the objective test results of the sole pressure distribution and the subjective evaluation of the test subject have certain guidance, but the experimental test subjects do not consider the industry and age factors and do not consider the flat foot and the specific foot shape due to the limitations of the experimental object and time. The impact of these factor can be considered in later research.

\section{CONCLUSIONS}

In order to study the actual distribution of foot pressure during long-time standing and the effects of sole hardness in pressure cushion and adjustment, this paper first introduces the basic theories about foot and then describes the experimental design and process. It uses Footscan to carry out the experiment on testees under different conditions and also conducts subjective assessment survey. After the experiment and the subjective assessment, this paper analyses the results and obtains the following conclusions:

(1) On bare foot, the feet have the poorest ability to adjust themselves. Footwear is the main buffer for foot pressure.

(2) During long-time standing, sole hardness has a great impact on the shoe comfort. Considering self-adjustment and fatigue resistance, medium hardness is the best.

(3) People who need to stand for a very long time at work should choose shoes that have heels and appropriate sole hardness.

\section{REFERENCES}

1. Genova, J.M., Gross, M.T., Effect of foot orthotics on calcaneal eversion during standing and treadmill walking for subjects with abnormal pronation, J Orthop Sports Phys Ther, 2000, 30, 11, 664-664, https://doi. org/10.2519/jospt.2000.30.11.664.

2. Lin, C.J., Lai, K.A., Chou, Y.L., Ho, C.S., The effect of changing the foot progression angle on the knee adduction moment in normal teenagers, Gait Posture, 2001, 14, 2, 85-91, https://doi. org/10.1016/s0966-6362(01)00126-6.

3. Fordzyun, Y., Andreyeva, O., Maistrenko, L., Level of comfort: artificial and natural shoe materials. a comprehensive assessment, Key 
Engineering Materials, 2013, 559, 25-30, https://doi.org/10.4028/www.scientific.net/ kem.559.25.

4. Brogioli, M., Gobbi, M., Mastinu, G., Pennati, M., Parameter sensitivity analysis of a passenger/seat model for ride comfort assessment, Exp Mech, 2011, 51, 8, 12371249, https://doi.org/10.1007/s11340-0109460-1.

5. Parker, D., Cooper, G., Pearson, S., Crofts, G., Howard, D., Busby, P., Nester C., A device for characterising the mechanical properties of the plantar soft tissue of the foot, Med Eng Phys, 2015, 37, 11, 1098-1098, https://doi. org/10.1016/j.medengphy.2015.08.008.

6. Zheng, Y.P., Huang, Y.P., Zhu, Y.P., Wong, M., He, J.F., Huang, Z.M., Development of a foot scanner for assessing the mechanical properties of plantar soft tissues under different bodyweight loading in standing, Med Eng Phys, 2012, 34, 4, 506-511, https:// doi.org/10.1016/j.medengphy.2011.11.005.

7. Schepers, H.M., Veltink, P.H., Ambulatory estimation of foot movement during gait using inertial sensors, J Biomech, 2007, 43, 16, 3138-43, https://doi.org/10.1016/j. gaitpost.2011.06.019.

8. Mifsud, N.L., Kristensen, N.H., Villumsen, M., Hansen, J., Kersting, U.G., Portable inertial motion unit for continuous assessment of in-shoe foot movement, Procedia Eng, 2014, 72, 72, 208-213, https://doi.org/10.1016/j. proeng.2014.06.035.

9. Ike, C.C., Exponential Fourier integral transform method for stress analysis of boundary load on soil, Mathematical Modelling of Engineering Problems, 2018, 5, 1, 33-39, https://doi.org/10.18280/mmep.050105.

10. Orlin, M., Stetson, K., Skowronski, J., Pierrynowski, M., Foot pressure distribution: methodology and clinical application for children with ankle rheumatoid arthritis, Clin Biomech, 1997, 12, 3, S17-S17, https://doi. org/10.1016/s0268-0033(97)88331-3.

11. Rosenbaum, D., Lübke, B., Bauer, G., Claes, L., Long-term effects of hindfoot fractures evaluated by means of plantar pressure analyses, Clin Biomech, 1995, 10, 7, 345-51, https://doi.org/10.1016/02680033(94)00004-q.

12. Zhang, S., Li, L., The differential effects of foot sole sensory on plantar pressure distribution between balance and gait, Gait Posture, 2013, 37, 4, 532-5, https://doi.org/10.1016/j. gaitpost.2012.09.012.

13. Cock, A.D., Willems, T., Witvrouw, E., Vanrenterghem, J., Clercq, D.D., A functional foot type classification with cluster analysis based on plantar pressure distribution during jogging, Gait Posture, 2006, 23, 3, 339-47, https://doi.org/10.1016/j. gaitpost.2005.04.011.

14. Ellegast, R., Kupfer, J., Reinert, D., Load weight determination during dynamic working procedures using the pedar foot pressure distribution measuring systems, Clin Biomech, 1997, 12, 3, S10-S10, https://doi. org/10.1016/s0268-0033(97)88321-0.

15. Hayes, A., Seitz, P., The average pressure distribution of the diabetic foot: can it be used as a clinical diagnostic aid, Clin Biomech, 1997, 12, 3, S3-S3, https://doi.org/10.1016/ s0268-0033(97)88309-x. 
16. Anbarian, M., Esmaeili, H., Effects of running-induced fatigue on plantar pressure distribution in novice runners with different foot types, Gait Posture, 2016, 48, 52-56, https://doi.org/10.1016/j. gaitpost.2016.04.029.
(C) 2018 by the author(s). Published by INCDTPICPI, Bucharest, RO. This is an open access article distributed under the terms and conditions of the Creative Commons Attribution license (http:// creativecommons.org/licenses/by/4.0/). 